\title{
Profil Kesulitan Belajar Matematika dan Self efficacy Matematis Siswa Sekolah Menengah di Riau
}

\author{
Zubaidah Amir MZ1 ${ }^{1}$, Ramon Muhandaz ${ }^{2}$ \\ 1,2 Pendidikan Matematika, Universitas Islam Negeri Sultan Syarif Kasim Riau \\ e-mail: ramon.muhan@uin-suska.ac.id
}

\begin{abstract}
ABSTRAK. Tujuan penelitian ini untuk mengetahui kesulitan belajar matematika dan self efficacy (SE) matematis siswa sekolah menengah di Riau. Kesulitan belajar dalam penelitian ini adalah kemampuan pemahaman konsep matematis. Metode penelitian yang digunakan dalam penelitian ini yaitu metode campuran (mixed methods). Lokasi penelitian adalah SMP/MTs di Riau yang diwakili oleh siswa di kota Pekanbaru dan Kampar yang melibatkan masing masing dua SMP dan dua MTs. Objek kajian dalam penelitian ini adalah kemampuan pemahaman konsep dan self efficacy matematis siswa. Dalam penelitian ini, pengumpulan data dilakukan melalui pemberian angket SE, tes pemahaman konsep matematis, wawancara dan dokumentasi. Hasil penelitian yang diperoleh bahwa self efficacy dan kemampuan pemahaman konsep siswa Pekanbaru lebih unggul dibandingkan siswa Kampar, baik pada SMP maupun pada MTs. Rata-rata kemampuan pemahaman konsep siswa di Pekanbaru tergolong tinggi, sedangkan sisiwa Kampar termasuk sedang. Secara umum, self efficacy siswa masih tergolong cukup baik. Beberapa faktor yang mempengaruhi SE dan pemahan konsep adalah pembelajaran yang kejar tayang dan perhatian atau dukungan dari orang tua di rumah
\end{abstract}

Keywords : Kesulitan belajar matematika, Pemahaman konsep matematis, Self efficacy.

\section{PENDAHULUAN}

Dalam proses pembelajaran, tidak menutup kemungkinan akan terdapat siswa yang mendapatkan kesulitan dalam belajarnya. Kesulitan belajar tersebut akan bervariasi untuk tiap siswa, ada yang hanya pada pelajaran tertentu, ada juga yang pada beberapa mata pelajaran sekaligus, atau hanya pada materi tertentu pada suatu mata pelajaran. Kesulitan belajar pada siswa tidak boleh dibiarkan tanpa penanganan atau mencari solusinya. Jika dibiarkan maka dikhawatirkan akan berdampak buruk pada hasil belajar selanjutnya. Penanganan hal ini perlu dilakukan oleh siswa itu sendiri maupun dengan bantuan orang tua, teman sebaya, dan terutama guru di sekolah.

Berbicara tentang kesulitan belajar, siswa yang mengalami kesulitan belajar merupakan siswa yang mengalami ketidakberhasilan dalam mengikuti pelajaran. Khairunnisak dkk (2017) menjelaskan bahwa siswa berkesulitan belajar dapat dilihat dengan adanya fenomena dari menurunnya prestasi dan semangat kerja siswa. Lebih lanjut mereka amenjelaskan bahwa beberapa gejala siswa mengalami kesulitan belajar diantaranya hasil belajar yang rendah, lambat dalam mengerjakan tugas, sikap yang tidak wajar, prilaku yang berkelainan, adanya gejala emosional yang kurang wajar.

Ketidakberhasilan siswa atau kesulitan belajar juga diperlihatkan berdasarkan data hasil UN dirilis oleh Pusat Penilaian Pendidikan Kementerian Pendidikan dan Kebudayaan. Data UNmenunjukkan bahwa untuk mata ujian matematika secara nasional masih tergolong belum memuaskan. Tahun 2018, rata-rata nilai UN berturut turut untuk tiap mata pelajaran Bahasa Indonesia, Bahasa Inggris, Matematika, dan IPA sebagai berikut: $(64,83),(50,42),(44,04)$, dan $(48,05)$ Rata-rata nilai UN tersebut di bawah 70 untuk semua mata pelajaran, termasuk 
matematika. Rata-rata nilai matematika tersebut masih kurang memuaskan. Begitu pula di tingkat provinsi Riau, rata-rata nilai UN untuk tiap materi dapat dilihat pada tabel 1 beikut:

Tabel 1. Persentase Siswa yang menjawab Benar Tahun Pelajaran 2017/2018 Propinsi Riau Tingkat SMP/MTs

\begin{tabular}{|c|c|c|c|}
\hline No & Materi yang diuji & Propinsi & Nasional \\
\hline 1 & Bilangan & 46,21 & 44,99 \\
\hline 2 & Aljabar & 41,71 & 41,88 \\
\hline 3 & Geometri dan Pengukuran & 42,83 & 41,40 \\
\hline 4 & Statistika dan Peluang & 40,24 & 45,71 \\
\hline & Rata-rata & 42,75 & 43,50 \\
\hline
\end{tabular}

Sumber: Pusat Penilaian Pendidikan Kementerian Pendidikan dan Kebudayaan

Data dari tabel tersebut menunjukkan persentase rata-rata persentase nilai matematika propinsi Riau dalam hal menjawab benar pada soal UN adalah 42,75\%, masih rendah dibandingkan secara nasional yang rata-rata nya 43,50\%. Sedangkan untuk nilai rata-rata keseluruhan nilai UN tingkat propinsi Riau adalah 43,38 dan untuk tingkat Pekanbaru sendiri adalah 44,92.

Berdasarkan data-data yang telah dipaparkan, maka peneliti menyimpulkan terdapat kesulitan dalam penguasaan materi matematika baik di SMP maupun MTs. Kesulitan belajar siswa banyak dialami oleh siswa dalam berbagai mata pelajaran, termasuk mata pelajaran yang membutuhkan proses berhitung seperti matematika. Matematika menjadi salah satu mata pelajaran yang diajarkan di lembaga pendidikan pada setiap jenis dan jenjang pendidikan. Ada sejumlah alasan perlunya siswa belajar matematika, (Murtadlo, 2014) yaitu: matematika merupakan sarana berfikir yang jelas dan logis; sarana untuk memecahkan masalah sehari-hari; sarana mengenal pola-pola hubungan dan generalisasi pengalaman; sarana untuk mengembangkan kreativitas; sarana untuk meningkatkan kesadaran terhadap perkembangan budaya. Sedangkan pembelajaran matematika adalah suatu proses yang diselenggarakan oleh guru untuk membelajarkan siswa guna memperoleh ilmu pengetahuan dan keterampilan matematika. Selain itu, pembelajaran matematika juga mengkonstruksi konsep-konsep atau prinsip-prinsip matematika dengan kemampuannya sendiri melalui proses internalisasi sehingga konsep tersebut terbangun kembali. Dengan demikian diharapkan pembelajaran matematika dapat berjalan maksimal dan meminimalkan munculnya siswa berkesulitan belajar matematika.

Kecermatan dan ketelitian baik secara teoritik maupun praktis itu selalu diajarkan dalam matematika. Untuk belajar matematika siswa dituntut lebih banyak latihan mengerjakan soal-soal. Dalam proses belajar mengajar matematika di sekolah, sering dijumpai beberapa siswa dengan prestasi belajar matematika rendah, bila disimak lewat prestasi nilai harian, nilai ulangan mid semester dan nilai ulangan sumatif. Nilai kurang yang dicapai oleh siswa berarti belum mencapai prestasi seperti yang diharapkan. Hal ini mungkin dikarenakan anak kurang tertarik pada mata pelajaran matematika, tidak adanya semangat untuk mempelajarinya, dan siswa merasa takut untuk belakar matematika.

Matematika sebagai mata pelajaran yang sulit dan menakutkan banyak diungkapkan oleh para ahli, diantaranya Sudarman (2012), Amir (2015) menjelaskan bahwa sampai dewasa ini sebagian siswa masih mempunyai kesan negatif terhadap matematika, matematika menakutkan, matematika sulit dan membosankan. Lebih lanjut, Amir menjelaskan bahwa banyak siswa menganggap matematika tidak menyenangkan, matematika merupakan ilmu yang kering, teoritis melulu dan hanya berisi rumus-rumus, dan tidak bersinggungan dengan realitas siswa. Matematika menjadi lebih bersifat teoritis dan abstrak (Atika dan Amir, 2016). Jika siswa mempunyai kesan negatif terhadap matematika, bahkan membenci karena kesulitannya, itu sama saja mereka tidak menyukai tantangan kesulitan yang ditawarkannya (Sudarman, 2012). Hal inilah harus menjadi perhatian guru dalam memperbaikinya.

Maka oleh sebab itu perlu adanya sikap percaya diri (seft efficacy) yang harus dimiliki oleh siswa untuk mengatasi kesulitan belajar matematika tersebut. Hal ini juga didukung oleh Peraturan Menteri Pendidikan dan Kebudayaan RI Nomor 64 tahun 2013, dijelaskan bahwa 
untuk tingkat kompetensi yang harus dimiliki oleh siswa kelas VII-IX itu adalah memiliki rasa ingin tahu, percaya diri (self efficacy), dan ketertarikan pada matematika.

Self efficacy (SE) adalah suatu pendapat atau keyakinan yang dimiliki oleh seseorang mengenai kemampuannya dalam menampilkan suatu bentuk perilaku dan hal ini berhubungan dengan situasi yang dihadapi oleh seseorang tersebut. SE bukanlah sekedar estimasi yang kaku mengenai tindakan seseorang diwaktu yang akan datang. Secara umum self-efficacy memiliki peranan dalam mempengaruhi pilihan orang dalam membuat dan menjalankan tindakan yang mereka kejar. Individu cenderung berkonsentrasi dalam tugas-tugas yang mereka rasakan mampu dan percaya dapat menyelesaikannya serta menghindari tugas-tugas yang tidak dapat mereka kerjakan. Self efficacy juga membantu menentukan sejauh mana usaha yang akan dikerahkan orang dalam suatu aktivitas, seberapa lama mereka akan gigih ketika menghadapi rintangan, dan seberapa ulet mereka akan menghadapi situasi yang tidak cocok.

Self efficacy juga memiliki fungsi penting dalam menghadapi pandangan bahwa matematika dianggap pelajaran yang sukar untuk dipahami dan pelajaran yang menakutkan bagi siswa yang berkemampuan rendah. Self efficacy has an impact on motivation, so it is also related to the success of students (Khaerunnisak, dkk. 2017). Fungsi penting tersebut adalah dalam hal kualitas strategi belajar dan mengontrol diri. Siswa dengan self efficacy tinggi memiliki kualitas strategi belajar yang lebih baik dan memiliki mengontrol diri yang lebih terhadap hasil belajar mereka dari pada siswa dengan self efficacy rendah.

Beberapa hasil riset menyatakan bahwa terdapat perbedaan kesulitan belajar matematika siswa dan self efficacy matematis siswa. Diantaranya MZ (2013), Maccoby dan Jacklyn (1974 dalam Zhu, 2007) yang menjelaskan terdapat perbedaan karakteristik gaya belajar dan kemampuan pada siswa laki-laki dan perempuan. Namun untuk siswa Sekolah Menengah Pertama Riau, hal itu belum tentu sama dengan hasil riset tersebut. Oleh sebab itu, peneliti ingin melihat bagaimana kesulitan belajar yang dialami siswa dan keyakinan siswa dalam menghadapi kesulitan belajar tersebut. Sehingga peneliti tertarik untuk melakukan penelitian dengan judul "Profil kesulitan belajar matematika dan selfefficacy matematis siswa Sekolah Menengah di Riau".

\section{METODE}

Metode penelitian yang digunakan dalam penelitian ini yaitu metode campuran (mixed methods) Untuk mendeskripsikan kesulitan belajar dan self eficacy akan lebih terperinci dengan data kualitatif, sedangkan untuk melihat hubungan signifikan antara self sficacy dan kesulitan belajar akan dilihat dengan data kuantitatif . Peneliti mengumpulkan dua macam data kuantitatif dan kualitatif secara simultan dalam satu tahap pengumpulan data, dalam waktu yang sama tetapi independen untuk menjawab rumusan masalah yang sejenis (Sugiyono, 2013).

Desain penelitian yang digunakan merupakan perpaduan kuantitatif-komparatif dan kualitatif-eksploratif, yaitu concurrent embedded design Teknik ini bertujuan untuk mengembangkan konsep, model, atau hipotesis lebih detil, yang berguna bagi penelitian lebih lanjut. Langkahlangkah penelitian model penggabungan Kuantitatif dan kualitatif dapat dilihat pada gambar 1 (Sugiyono, 2013).

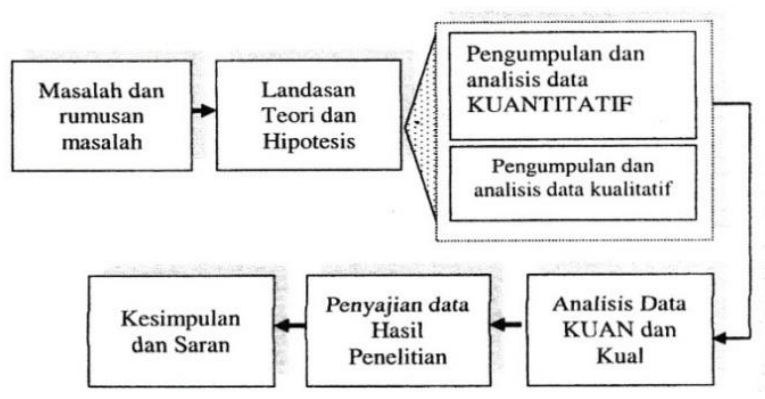

Gambar 1. Metode Campuran Concurrent Embedeed 
Lokasi penelitian adalah sekolah menengah (SMP/MTS) di propinsi Riau yang diwakili oleh siswa di kota Pekanbaru dan Kampar yaitu SMP Bina Plus Peknabaru, MTs Al-Muttaqin, SMP 4 Tambang dan MTs Assalam Kampar. Subjek dalam penelitian ini adalah kemampuan pemahaman konsep matematis dan selfefficacy matematis siswa. Penentuan subjek dalam penelitian mix method ini bersifat sementara dan menggunakan teknik purposive sampling. Dalam penelitian ini, peneliti menggunakan empat teknik pengumpulan dalam melakukan pengumpulan data yakni survey (angket), tes, wawancara dan dokumentasi.

\section{HASIL DAN PEMBAHASAN}

\section{Data Hasil Survey untuk Self Efficacy}

Data mengenai kepercayaan diri self efficacy siswa diperoleh melalui angket self efficacy (SE). Indikator SE yang digunakan dalam penelitian ini (Bandura, 1986) adalah: (1) kepercayaan diri dalam menghadapi situasi yang tidak menentu yang mengandung kekaburan, tidak dapat diramalkan dan penuh tekanan, (2) keyakinan akan kemampuan dalam mengatasi masalah atau tantangan yang muncul, (3) keyakinan mencapai target yang telah ditetapkan, dan (4) keyakinan akan kemampuan menumbuhkan motivasi, kemampuan kognitif dan melakukan tindakan yang diperlukan untuk mencapai suatu hasil. Adapun hasil yang diperoleh dapat dilihat pada tabel berikut:

Tabel 2. Hasil Survey Self Efficacy

\begin{tabular}{|c|c|c|c|c|c|}
\hline \multirow{2}{*}{$\begin{array}{l}\text { Indikator } \\
\text { Diamati }\end{array}$} & \multicolumn{4}{|c|}{ Persentase Self Efficacy yang Diamati } & \multirow{2}{*}{$\begin{array}{l}\text { Rata-rata } \\
\text { per } \\
\text { indikator }\end{array}$} \\
\hline & $\begin{array}{l}\text { MTs } \\
\text { Assalam } \\
\text { Kampar }\end{array}$ & $\begin{array}{l}\text { SMP N } 4 \\
\text { Tambang }\end{array}$ & $\begin{array}{c}\text { MTs Mutaqin } \\
\text { Pekanbaru }\end{array}$ & $\begin{array}{c}\text { SMP Bina Plus } \\
\text { Pekanbaru }\end{array}$ & \\
\hline $\begin{array}{l}\text { Kepercayaan diri dalam } \\
\text { menghadapi situasi yang tidak } \\
\text { menentu, mengandung kekaburan, } \\
\text { tidak dapat diramalkan dan penuh } \\
\text { tantangan }\end{array}$ & $52,5 \%$ & $67,5 \%$ & $77,5 \%$ & $75 \%$ & $68,13 \%$ \\
\hline $\begin{array}{l}\text { Keyakinan akan kemampuan } \\
\text { mengatasi masalah atau tantangan } \\
\text { yang muncul }\end{array}$ & $55 \%$ & $62,5 \%$ & $69,6 \%$ & $65,2 \%$ & $63,08 \%$ \\
\hline $\begin{array}{l}\text { Keyakinan mencapai target yang } \\
\text { telah ditetapkan }\end{array}$ & $47,5 \%$ & $52,5 \%$ & $50 \%$ & $62,5 \%$ & $52,13 \%$ \\
\hline $\begin{array}{l}\text { Keyakinan akan kemampuan } \\
\text { menumbuhkan motivasi, kognitif } \\
\text { dan melakukan tindakan yang } \\
\text { diperlukan untuk mencapai suatu } \\
\text { hasil }\end{array}$ & $60 \%$ & $70 \%$ & $75 \%$ & $75 \%$ & $70 \%$ \\
\hline Rata-rata self efficacy per-sekolah & $53,75 \%$ & $63,13 \%$ & $68,03 \%$ & $69,43 \%$ & \\
\hline
\end{tabular}

Berdasarkan tabel 3 dapat dibuat gambar seperti di bawah ini: 


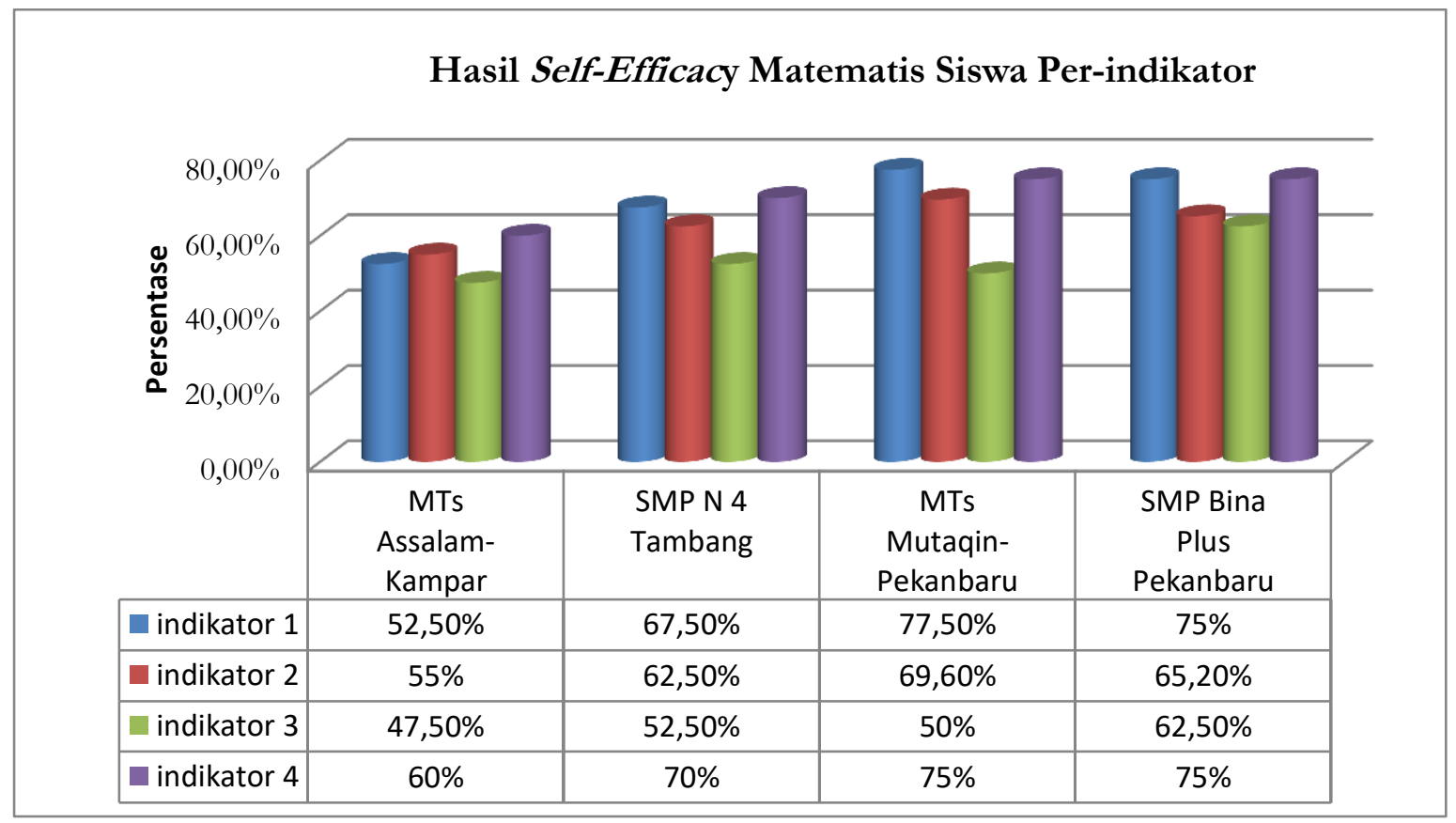

Gambar 2. Self Efficacy Matematis Siswa Per-indikator

Berdasarkan Tabel 3 dan gambar 2 di atas terlihat bahwa persentase self efficacy siswa bervariasi dalam rentangan 47,5\% dengan kategori cukup baik sampai dengan 77,5\% dengan kategori baik. Jika dilihat dari rata-rata persentase secara keseluruhan terendah terdapat pada indikator self efficacy yang ketiga yaitu keyakinan dalam mencapai target yang telah ditentukan sebesar 53,13\%, dan rata-rata persentase tertinggi terdapat pada indikator self-efficacy yang keempat yaitu keyakinan dalam menumbuhkan motivasi, kognitif dan menentukan tindakan yang diperlukan untuk mencapai hasil yaitu 70\%. Secara umum, terlihat self-efficacy siswa masih tergolong cukup baik.

Selain itu, hasil angket yang telah diisi oleh siswa kelas VIII diketahui bahwa sebagian besar siswa mengalami kesulitan dalam belajar matematika dikelas VIII karena proses pembelajaran yang dirasa sulit dan materinya juga sulit untuk dipahami sehingga membuat siswa bosan dalam pembelajaran matematika karena banyak rumus-rumus matematika yang harus dipahami. Hal ini mengakibatkan siswa kurang berminat dalam mempelajari matematika terutama dengan materi yang mereka rasa baru. Ditambah lagi materi yang lebih banyak dibanding kurikulum sebelumnya dengan waktu yang sama.

\section{Hasil Wawancara}

Berdasarkan hasil wawancara diperoleh kesimpulan bahwa peran orang tua yang kurang memperhatikan belajar putra putrinya, mereka menjelaskan bahwa orang tua mereka sibuk dengan pekerjaannya tiap hari. Orang tua yang memiliki sedikit waktu untuk anak-anaknya, sehingga banyak siswa yang semangat belajarnya kadang naik kadang turun. Ada pula siswa yang memberi alasan bahwa mereka mempunyai penyakit tertentu yang memang jika kambuh membuat tidak bisa berkonsentrasi dalam belajar, sehingga ada beberapa materi matematika tidak bisa dipahami dengan baik.

Ketika pembelajaran, guru hanya sesekali menggunakan media pembelajaran. Pada materi bangun ruang sisi datar, media yang digunakan guru adalah benda berbentuk bangun ruang dalam kehidupan sehari-hari dan slide power point, model pembelajaran tidak selalu menyenangkan bagi siswa. Jika materi masih banyak dan waktunya sudah mendekati ujian maka mengajarnya dipercepat.

Dengan kurikulum saat ini ada beberapa siswa yang merasa tidak enjoy, mereka menganggap pembelajarannya sangat rumit dan susah dimengerti. Dalam pembelajaran mereka 
tidak diminta untuk melakukan eksperimen, karena yang pernah eksperimen itu pelajaran fisika, biologi dan kimia saja. Penilaian pada pembelajaran matematika yaitu sikap dan keterampilan karena tidak hanya kognitif saja yang dinilai. Namun ada siswa yang tidak suka dengan penilaian yang banyak dan ribet menurutnya. Siswa jarang diminta mengumpulkan semua hasil yang diperoleh setelah pembelajaran selama satu semester.

\section{Hasil Tes untuk kesulitan belajar Matematika}

Berdasarkan hasil temuan menunjukkan siswa masih kesulitan dalam menyelesaikan soal pemahaman konsep. Rata-rata skor kemampuan pemahaman konsep matematis siswa dan di kelompokkan pada 3 kategori tinggi, sedang dan rendah. Kesemuannya dikomunikasikan secara ringkas pada tabel profil pemahaman konsep matematis siswa SMP/MTS berikut :

Tabel 3 HasilTes Diagnostik Kesulitan Belajar dari soal Pemahaman Konsep

\begin{tabular}{|c|c|c|c|c|c|c|c|c|c|}
\hline \multirow[t]{3}{*}{ No } & \multirow{3}{*}{$\begin{array}{l}\text { Indikator } \\
\text { Pemahaman } \\
\text { Konsep } \\
\text { Matematis }\end{array}$} & \multicolumn{5}{|c|}{ Pekanbaru } & \multicolumn{3}{|c|}{ Kampar } \\
\hline & & \multicolumn{2}{|c|}{ SMP Bina Plus } & \multicolumn{2}{|c|}{ MTS Muttaqin } & \multicolumn{2}{|c|}{ SMPN 4 Tambang } & \multicolumn{2}{|c|}{ PP. As-Salam } \\
\hline & & Nilai & Kategori & Nilai & Kategori & Nilai & Kategori & Nilai & Kategori \\
\hline 1 & $\begin{array}{l}\text { Menyatakan ulang } \\
\text { sebuah konsep }\end{array}$ & 88.7 & Tinggi & 85.4 & Tinggi & 84.6 & Tinggi & 80.3 & Tinggi \\
\hline 2 & $\begin{array}{l}\text { Mengklasifikasikan } \\
\text { objek sesuai } \\
\text { dengan konsepnya }\end{array}$ & 87.4 & Tinggi & 82.2 & Tinggi & 80.7 & Tinggi & 82.4 & Tinggi \\
\hline 3 & $\begin{array}{l}\text { Mengidentifikasi } \\
\text { dan membuat } \\
\text { contoh dan bukan } \\
\text { contoh konsep }\end{array}$ & 74.4 & Sedang & 70.2 & Sedang & 72.5 & Sedang & 74.1 & Sedang \\
\hline 4 & $\begin{array}{l}\text { Menyajikan } \\
\text { konsep dalam } \\
\text { berbagai bentuk } \\
\text { representasi } \\
\text { matematika }\end{array}$ & 72.3 & Sedang & 68.7 & Sedang & 70.4 & Sedang & 68.6 & Sedang \\
\hline 5 & $\begin{array}{l}\text { Mengidentifikasi } \\
\text { sifat-sifat suatu } \\
\text { konsep dan } \\
\text { mengenal syarat } \\
\text { yang menentukan } \\
\text { suatu konsep }\end{array}$ & 70.6 & Sedang & 70.3 & Sedang & 66.3 & Sedang & 65.6 & Sedang \\
\hline 6 & $\begin{array}{l}\text { Menggunakan, } \\
\text { memanfaatkan dan } \\
\text { memilih prosedur } \\
\text { tertentu }\end{array}$ & 82.3 & Tinggi & 81.4 & Tinggi & 55.7 & Rendah & 54.3 & Rendah \\
\hline 7 & $\begin{array}{l}\text { Mengaplikasikan } \\
\text { konsep atau } \\
\text { algoritma ke } \\
\text { pemecahan } \\
\text { masalah }\end{array}$ & 80.7 & Tinggi & 76.6 & Tinggi & 52.6 & Rendah & 52.4 & Rendah \\
\hline & Rata-rata nilai & 79.48 & Tinggi & 76.4 & Tinggi & 68.97 & Sedang & 68.24 & Sedang \\
\hline & rata-rata wilayah & & & & & & & 68.61 & \\
\hline & Rata-rata SMP & & & & & 23 & & & \\
\hline & Rata-rata MTS & & & & & 32 & & & \\
\hline
\end{tabular}

Rata-rata kemampuan pemahaman konsep matematis siswa SMP Plus Bina Pekanbaru dan MTs Mutaqqin termasuk kategori tinggi, dengan masing-masing rata-rata nilai yang didapat adalah 79,48. dan 76,4. Rata-rata kemampuan pemahaman konsep matematis siswa SMPN 4 Tambang dan PP. As-Salam termasuk kategori sedang, dengan rata-rata nilai masing-masing adalah 68,97 dan 68,24. Jika kita membandingkan rata-rata nilai pemahaman konsep matematis siswa antar SMP, pada SMP di wilayah Pekanbaru memperoleh nilai rata-rata 79,48 nilai tersebut lebih tinggi 
dibandingkan pada SMP di wilayah Kampar yang memperoleh nilai 68,97. Jika kita membandingkan hasil rata-rata nilai pemahaman konsep matematis siswa antar MTs, pada MTs di wilayah Pekanbaru memperoleh nilai rata-rata 76,4 nilai tersebut lebih tinggi dibandingan pada MTs di wilayah Kampar yang memperoleh nilai 68,24.

Dapat kita simpulkan jika kita bandingkan nilai rata-rata antar wilayah yaitu Pekanbaru dan Kampar nilai rata-rata tertinggi pada pemahaman konsep matematis siswa adalah lebih tinggi pada sekolah di wilayah Pekanbaru dengan rata-rata nilai 77,94 sedangkan pada sekolah di wilayah Kampar memperoleh rata-rata nilai 68,61. Jika kita membandingkan rata-rata nilai pemahaman konsep matematis siswa antara SMP maupun MTs tanpa melihat wilayah,maka pada SMP memperoleh nilai rata-rata lebih tinggi dibandingan MTs karena pada SMP nilai rata-rata yang didapat adalah 74,23 dan pada MTS adalah 72,32.

Pada hasil profil pemahaman konsep matematis siswa SMP/MTS di Pekanbaru dan Kampar dapat kita komunikasikan dalam bentuk grafik berikut :

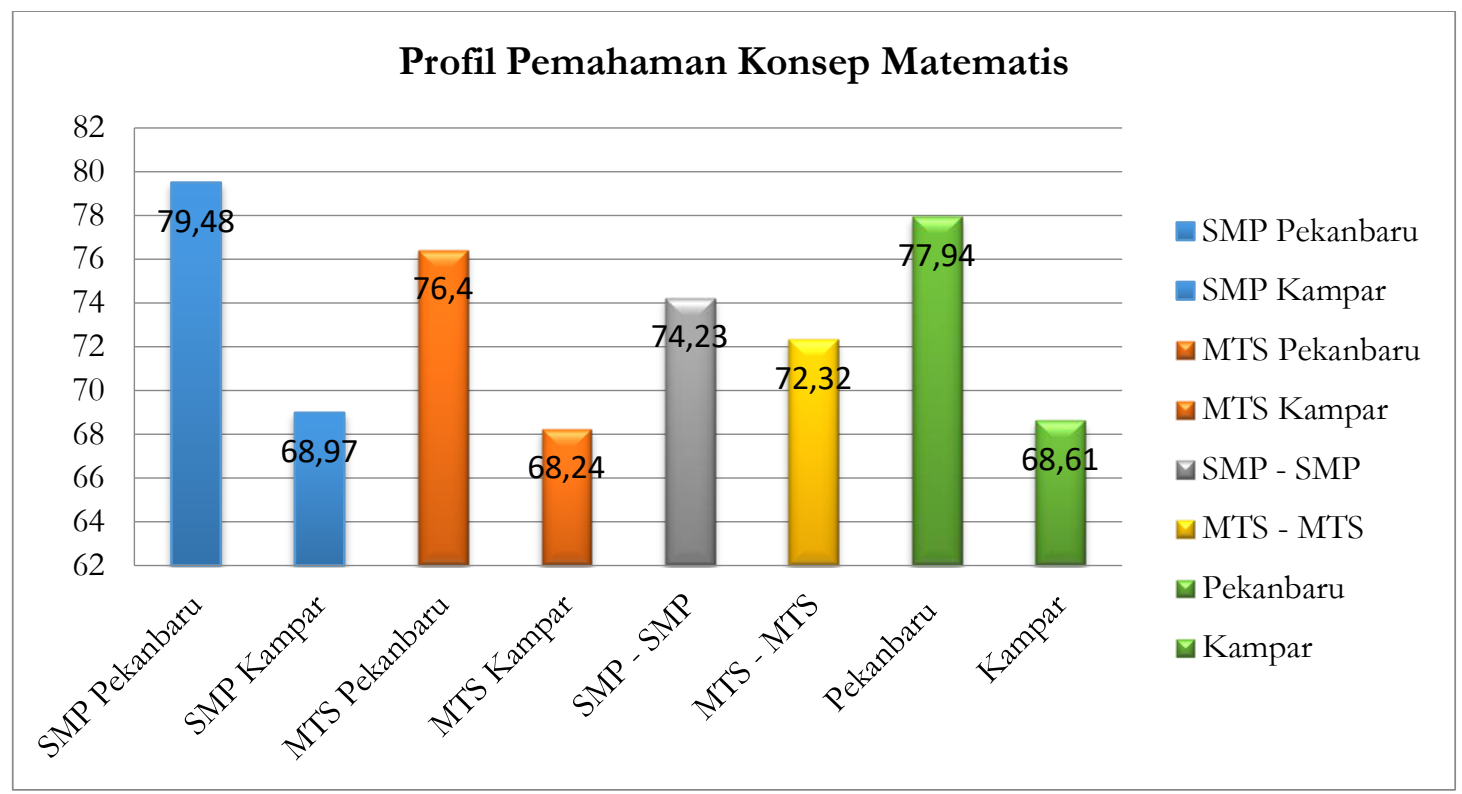

Gambar 3. Profil Kemampuan Pemahaman Konsep Matematis

Pada grafik ini terlihat jelas perbedaan hasil nilai pemahaman konsep matematis pada SMP/MTs di wilayah Pekanbaru dan Kampar. Sehingga terlihat, pada wilayah Pekanbaru lebih unggul dibandingan wilayah Kampar baik pada SMP maupun MTs, hal yang mungkin mempengaruhi hal tersebut adalah siswa mengalami kesulitan dalam hal belajar baik dalam diri siswa tersebut, lingkungan maupun fasilitas yang ada disekolah tersebut.

Berdasarkan hasil tes diagnostik yang dilakukan, maka dapat disajikan beberapa contoh jawaban siswa untuk melihat kesulitan belajar sesuai dengan indikator kesulitan belajar menurut Coney (dalam Abdurrahman, 2012), yaitu : (1) kesulitan pada tahap konsep, kesulitan pada tahap konsep yang dialami siswa adalah siswa sudah mampu memahami konsep himpunan untuk menyelesaikan soal cerita yang berkaitan dengan konsep himpunan, hal ini dapat di lihat dari indikator 1-4 yang sudah memperoleh nilai dengan kategori tinggi (2) kesulitan pada prinsip/prosedur, siswa masih belum bisa mencari prinsip atau prosedur yang tepat digunakan dalam penyelesain masalah, hal tersebut dapat dilihat pada indikator 6 yang masih banyak pada kategori rendah, (3) kesulitan pada tahap operasi hitung, siswa tidak dapat menyelesaikan soal yang sesuai dengan prosedur atau tidak sistematik. Pada tahap prosedur siswa belum mampu memilih prosedur yang tepat sehingga masih banyak siswa yang salah dalam menyelesaikan masalah. Hal tersebut juga dapat dilihat pada indikator ke-7 dimana masih ada sekolah yang tergolong kategori rendah walaupun sekolah yang berada di kota sudah tergolong tinggi. 


\section{KESIMPULAN}

Berdasarkan analisis hasil penelitian dapat disimpulkan bahwa self efficacy dan kemampuan pemahaman konsep siswa Pekanbaru lebih unggul dibandingkan siswa Kampar, baik pada SMP maupun pada MTs. Persentase self efficacy siswa bervariasi dalam rentangan 47,5\% dengan kategori cukup baik sampai dengan 77,5\% dengan kategori baik. Secara umum, self efficacy siswa masih tergolong cukup baik. Nilai rata-rata kemampuan pemahaman konsep matematis siswa Pekanbaru dan Kampar berturut-turut 77,94 dan 68,61. Rata-rata nilai pemahaman konsep matematis siswa antara SMP maupun MTs tanpa melihat wilayah, maka pada SMP memperoleh nilai rata-rata lebih tinggi dibandingan MTs, rata-rata kemampuan pemahaman konsep siswa berturut-turut adalah 74,23 dan pada MTs adalah 72,32. Beberapa faktor yang mempengaruhi self efficacy siswa dan kemampuan pemahaman konsep adalah pembelajaran yang kejar tayang, penggunaan media pembelajaran yang kurang efektif dan kurangnya perhatian atau dukungan dari orang tua di rumah.

\section{REFFERENSI}

Amir, Z. (2015). Mengungkap seni bermatematika dalam pembelajaran. Suska Journal of Mathematics Education, 1(1), 60-78

Atika, N., \& Amir, Z. (2016). Pengembangan LKS berbasis pendekatan RME untuk menumbuhkembangkan kemampuan berpikir kritis matematis siswa. Suska Journal of Mathematics Education, 2(2), 103-110.

Abdurrahman, M. (2012). Anak berkesulitan belajar: teori, diagnosis, dan remediasi. Jakarta: PT. Rineka Cipta

Murtadlo, A. (2014). Kesulitan belajar (learning difficult) dalam pembelajaran matematika. Jurnal Edu-Math, 4.

Bandura. (1986). Sosial fondation of thought and a chon a social cognitive theory. Englewood Cliffs. New York: Prestice Hall

Khaerunisak, K., Kartono, K., Hidayah, I., \& Fahmi, A. Y. (2017). The analysis of diagnostic assessment result in pisa mathematical literacy based on students self-efficacy in RME learning. Infinity Journal, 6(1), 77-94.

Sudarman, B. (2012). Adversity quotient kajian kemungkinan pengintegrasiannya dalam pembelajaran matematika. Aksioma, 1(01).

Sugiyono. (2013). Metode Penelitian Pendidikan Pemdekatan Kuantitatif, Kualitatif, dan R\&D. Bandung: Alfabeta.

MZ, Z. A. (2013). Perspektif gender dalam pembelajaran matematika. Marwab: Jurnal Perempuan, Agama Dan Jender, 12(1), 15-31.

Zhu, Z. (2007). Gender differences in mathematical problem solving patterns: A review of literature. International Education Journal, 8(2), 187-203. 